\title{
Marketing Economic Ideas: The Problem with Capital
}

\author{
David Colander \\ Middlebury College, Middlebury, Vermont 05753, USA.
}

Eastern Economic Journal (2015) 41, 1-5. doi:10.1057/eej.2014.49;

published online 29 September 2014

Thomas Piketty's book, Capital in the 21st Century, is a US publishing phenomenon. Somehow, a 600 page dense economics tome - a translation of a French book that was no French publishing phenomenon - became a best seller in the United States. This, despite the fact that:

(1) Its two stated major conclusions that (a) "one should be wary of any economic determinism in regard to inequalities of wealth and income" and (b) "the dynamics of wealth distribution reveal powerful mechanisms pushing alternatively toward convergence and divergence" (pp. 20, 21) are modest. The book does not claim that divergence (more inequality) is inevitable or that in the future convergence (more equality) might not occur. It simply claims that, theoretically, convergence is not inevitable. Perhaps some people thought it was, but convergence was never a theoretical conclusion of economics.

(2) Its empirical findings that the in-country wealth distributions have become more unequal recently, and hence the convergence we saw in the post-war era has reversed, are more confirmations of what most people, and most economists, believed before Piketty's book; they are not a surprise or novel.

(3) The book is a dense tome that will put most economists to sleep, and will be impenetrable by most lay readers.

So why the hoopla? I propose two reasons:

(1) Right place, right time, right person. It was a useful vehicle to raise some questions that a lot of people, including me, believe should be raised.

(2) Brilliant, but highly misleading, marketing.

\section{RIGHT TIME, RIGHT PLACE, RIGHT PERSON}

The US idea mavens, or at least the eastern liberal establishment idea mavens, have been expecting and wanting a discussion of the growing inequality in wealth and income distribution for decades. The economics profession hasn't provided it — the profession has a strong tendency to simply disregard the issue. Instead, mainstream economists vaguely 
talk about a marginal productivity theory of distribution that was long ago abandoned as inadequate as a full theory of distribution.

The profession has done little to extend the theory, and show how it blends with social and institutional criteria to create the income distribution we have. Instead, the economics profession avoids the distribution issue in much of its theoretical work by assuming that costless lump sum transfers exist that can get us to the income distribution society wants. That implicit assumption allows it to talk only about allocative efficiency. Of course we don't have costless lump sum transfers. Never have, never will.

The need to focus on income distribution, and the problems with economic theory, has been much discussed in economics, but that work has usually acquired the prefix "heterodox," which within the sociology of the economics profession causes it to be dismissed without serious consideration. What differentiates this book is that it is written by a "reformed insider." Piketty is a well-connected, technically trained economist who received his Ph.D. at 22, and who formerly taught at MIT. That pedigree and his wellconnectedness likely account for the kid gloves used by many top economists as they have reviewed and commented on this book. What do I mean by kid gloves? I mean overfavorable reviews that overlook weaknesses in the book and comments such as "economics has yet to get over its childish passion for mathematics," which if made by anyone else, would cause them to stop reading and to pan the book.

Given this failure of economics to deal with the income distribution issue, there is a natural tendency for reporters and economics observers to look for some entré into the wealth and income distribution issue. So they were primed for any book that raised the question. Piketty's book, and the broader research program that Piketty is involved with (work with economists such as Tony Atkinson and Emmanuel Saez) does. That overall work is commendable and important; I am a strong fan of it. But this book is just a small part of that research program, and Piketty's connection to that larger important project does not make this a great book, or justify the rave reviews the book has gotten.

The reality is that the book is not a path-breaking look at the problem of income distribution and what to do about increasing inequality appropriate for lay readers. It is an academic book concerned with fine points regarding data collection, blended with some loose discussions of theory and policy. It is not a theoretical or policy contribution to the income distribution debate. Its discussion of theory is problematic and its discussion of policy is, quite frankly, pedestrian. So while a discussion of income and wealth distribution is overdue, this is a strange vehicle to use for that purpose. Thus we must look for some other explanation for the book's success.

\section{BRILLIANT BUT HIGHLY MISLEADING, MARKETING}

An important part of that other explanation is Harvard University Press' brilliant marketing strategy; that marketing turned a dense academic tome into a New York Times best seller. How did it do it?

First, by mistitling the book. A basic rule of publishing is that the title is 30 percent of the game, and the title of the French edition of the book was printed on the cover as follows:

$$
\text { Le capital }
$$

au xxie siècle

That title is not the path to a best seller. It is not catchy, and it doesn't bring to mind the controversy necessary to excite a potential reader.

Harvard didn't follow the French Publisher's presentation of the title. Instead, they essentially entitled the book Capital. They did this by capitalizing and significantly 
increasing the type size of CAPITAL, printing it in red, and so diminished the print size of the second part of the title so that it was seen as a subtitle rather than a part of the main title. Then they placed a red border on the book jacket, resulting in the following:

\section{CAPITAL \\ in the Twenty-First Century}

The result of these changes was to create a connection in reader's minds between Piketty's book and Karl Marx's book, Capital. This connection encouraged people to think that this was a book by a MIT-certified economist that raises similar issues to those Marx raised. That's a book of interest to lots of people. The misleading aspect of this is that the book has nothing to do with Marxism - the author isn't a Marxist; he is a mainstreamtrained economist and that training doesn't include even reading Marx, much less seriously dealing with his ideas. It is a marketing campaign worthy of Ron Popeil.

\section{But wait, there's more!}

Even the "Capital" in the title is misleading. The reason is that the book isn't even about capital in the way either Marx or modern economists define it. Marx defined capital as a set of power relationships that went far beyond economics and economic models. Modern economists have largely dropped the use of capital as a measurable aggregated concept, but to the degree it is used without qualifier, capital refers to a physical set of factors used in production. It is a concept that theoretically should be unaffected by fluctuations in financial value. Piketty's concept of capital is affected by financial fluctuations.

A much more honest title, capturing what Piketty's book is about would be "Wealth." Wealth is measured in financial terms, and can fluctuate greatly. Piketty recognizes that his concept of capital is different than Marx's and MIT's but never really discuses the differences carefully. Rather he treats the definition in a cavalier manner and often interchanges the capital concept with wealth. Had he chosen the more appropriate title "Wealth at the Dawn of the 21st Century," I suspect I wouldn't be writing about his book.

The book has almost no discussion of the theoretical problems with the use of the concept capital, and its one description of the historical debate about capital is, from what I remember about the capital debates, seriously flawed. Specifically, Piketty presents the Cambridge capital controversy (a 1970s debate between economists at Cambridge, England, and Cambridge, Massachusetts) as a debate about whether growth is knife-edge. He claims that "there was no real justification of the suspicions of the British."(p. 232) He writes that "the virulence — and at times sterility — of the Cambridge capital controversy was due in part to the fact that participants on both sides lacked the historical data needed to clarify the terms of the debate."

That summary of the debate and his assessment that it occurred because the participants "lacked historical data" seems weird to me. As I remember the capital controversy, it was not about historical data at all. It was a theoretical debate about whether the aggregation of capital into a single concept made sense as part of an aggregate production function. Cambridge, England said the aggregation into a single variable didn't make theoretical sense. Cambridge, Massachusetts initially said it did make sense, but then modified its stance to say that yes, if one wanted to be precise about it, the aggregation theoretically didn't make sense, but then they addended that concession with an argument that the aggregation didn't do that much harm if one didn't take the capital measure too seriously. The debate ended when Chris Bliss (at neutral Oxford) redid the analysis in a general equilibrium framework that had no need for a single measure of capital. After that, economists stopped talking about aggregate capital as a usefully measurable concept. 
Somehow, in Piketty's summary of this debate, a theoretical controversy about the problems with the very concept of capital as a measurable concept - a debate that would seriously undermine his whole approach - has become a debate about historical data, and Piketty's work is supposed to help resolve it. Since he taught for a couple of years at MIT, maybe that's the way they remember it there, but from a non-Cambridge, Massachusetts' vantage point, his remembrance reflects some serious cognitive dissonance.

\section{But wait, there's even more!}

Much of the most recent concern in the United States about income inequalities is not about capital income at all. It is about relative pay and wage structure. That's because the recent change in wealth distribution has resulted from a major shift in wage structure, not from a shift in capital income. In the US higher level managerial and CEO jobs have rocketed in pay, while lower level job pay has remained stagnant. For example, the ratio of CEO pay relative to the average wage was 20-1 in 1965; today it is more like 300-1.

That change, and its long-run implications, bothers people a lot, including me. And it should. But it has little to do with the return on capital to capital owners. Piketty recognizes this; he points out that about 75 percent in the recent increase in inequality is because of the divisions of wage income with high-end workers doing much better than low wage workers. But he then goes on to talk as if the issue is primarily about returns to capital.

\section{But wait; if you continue reading, there's even more!}

Much of the positive spin about the book relates to the book's empirical findings. While I admire the hard work that went into collecting the data, I don't see the empirical findings as accounting for the book's layperson's appeal. For me, at least, the empirical findings had little surprise in them - they were what I would have expected a researcher to find, given the assumptions he was making. By that I mean that Piketty's empirical findings have made our knowledge about income and wealth distribution more precise, but he did not discover something that wasn't part of conventional wisdom.

I suspect this isn't only true for me, but also for anyone who has carefully followed the studies on income inequality. In fact, the longtime ongoing work on distribution by Ed Wolff at NYU, or by Jamie Galbraith at the University of Texas Inequality project, comes to very similar conclusions. (I've always seen Galbraith's work as a continuation of Kuznets's work, whereas Piketty states that "no one has ever systematically pursued Kuznets's work.") So my concern with Piketty's empirical work is not the same as Chris Giles of the Financial Times criticism that it is shoddy, and full of mistakes that lead to incorrect conclusions. My criticism is that it doesn't change educated conventional wisdom, and that the definitional problems in defining capital are so great that careful empirical measurements of capital do not add a lot to our understanding.

\section{But wait; yes there's even more!}

I would probably be less critical of the book if the book had some interesting or novel policy suggestions that would lead to a useful conversation about income distribution policy. Unfortunately it doesn't. The book's policy suggestions are pedestrian and superficial. He focuses on two policies - a world-wide wealth tax, and a higher degree of progressivity in the income tax. Both of those have long been on the liberal agenda. But politically both have been difficult to implement.

The problem of progressivity of the income tax is that in practice any highly progressive income tax has involved so many loopholes that its actual progressivity is lost. As Bill 
Vickrey showed long ago in Agenda for Progressive Taxation, a highly progressive tax is technically feasible, but it is exceedingly complex. That complexity has made it ripe for special interests to create so many loopholes that even supporters agree that it is unmanageable. The policy question is: How to develop a politically implementable highly progressive income tax without loopholes? Perhaps it can be done, but it is highly unlikely with existing political divisions in the US; Piketty doesn't show us the way.

The problems with a global wealth tax are even more severe. There is no global government to implement it, nor is any on the horizon. Any serious discussion of those policies would outline how technically and politically one could implement them. The book doesn't provide that.

\section{CONCLUSION}

If most other discussions of Piketty's book had not been so uniformly positive and laudatory, I would not have written this column. Piketty's is not a bad book, and the broader research program that he is associated with has contributed much to the profession's understanding of income inequality. But it is a book for economists, not for the lay public, and the "path breaking" and "revolutionary" claims for it are far overdone.

That this book is not a revolutionary book appropriate for lay readers is not surprising. Modern economics training is highly technical; it does not provide students with training in economic history, history of economic thought, methodology, or the subtleties of drawing inferences from highly incomplete data, all abilities that one needs to write a book that would meet the claims that reviewers are making for this book. Modern economists aren't selected for, nor trained in traits useful in writing a book appropriate for the lay public. As I have pointed out elsewhere, most students with proclivities toward that end don't go into economics, and those who do (and admit it on their application) are unlikely to be accepted into top programs. If John Kenneth Galbraith or Milton Friedman applied to a top graduate school today, they would be rejected. (http://econjwatch.org/articles/whyare-there-no-milton-friedmans-today)

The reality is that Piketty's book is not a follow-up to Marx's Capital, nor is it an important theoretical contribution to our understanding of wealth and income distribution. Too many reviewers seem to miss those simple points. Moreover, Piketty doesn't claim that the book is revolutionary. He presents his work openly and with appropriate modesty. Most readers, however, won't recognize this because they will not make it through this dense book about nitty gritty empirical data problems. So they will know it only by the reviews and commentary. Unfortunately, the majority of reviewers and commentators give the wrong impression of the book, and I hope this commentary somewhat offsets it. 